\title{
Managing reindeer and wildlife on Alaska's Seward Peninsula
}

\author{
Jim Dau

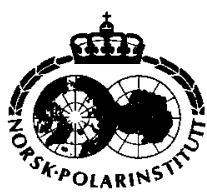

When reindeer (Rangifer tarandus tarandus) were introduced to Alaska's Seward Peninsula between 1892 and 1902, other ungulates were not present and large predators were either absent or less abundant than after reindeer were established. During the next 100 years reindeer numbers and distribution increased and declined precipitously on the Seward Peninsula; wildlife species repopulated this region through natural processes or translocations by man; the non-Native human population of Alaska increased dramatically and wildlife management became an issue of national concern creating diverse public desires regarding resource use; and both range and wildlife became intensively managed through complex, politicized processes. This paper provides an historical overview of reindeer and wildlife abundance on the Seward Peninsula during the 20th century and describes the effects of wildlife on the reindeer industry. Cooperative public processes have been initiated to bring diverse public interests together; meld indigenous, scientific and local knowledge of resources; and supplement governmental wildlife management programmes. Even so, the Seward Peninsula reindeer industry has been severely impacted by wildlife, especially caribou $(R . t$. granti $)$.

J. Dau, Alaska Dept. of Fish and Game, Box 689, Kotzebue, AK 99752, USA.

Reindeer were introduced to Alaska's Seward Peninsula during 1892-1902 to provide: 1) a dependable source of red meat for local Inupiat; 2) an alternative to dog teams for transportation (Vorren 1994); and 3) a mechanism for social change whereby Inupiat would be converted from a hunter-gatherer subsistence society to contributors to the cash economy of the United States, and from shamanists to Christians (Jackson 1906).

For approximately 40 years after their introduction, reindeer abundance and distribution rapidly expanded on and beyond the Seward Peninsula as reindeer exploited an open niche and herders aggressively expanded their industry. By the mid1930 s, reindeer increased to perhaps as many as 641000 animals throughout Alaska (Stern et al. 1980).

Beginning in the mid- to late 1930 s, social, political, economic and biological factors caused reindeer numbers to decline throughout Alaska (Stern et al. 1980). By 1950, few viable reindeer herds occurred beyond the Seward Peninsula, where numbers stabilized at roughly 25000 animals. During the late 1980s reindeer numbers began to decline again even on the peninsula.

Despite fluctuations in abundance, reindeer herding is important to the social structure and economy of Seward Peninsula villages. Currently, 14 herders hold designated reindeer ranges on the Seward Peninsula. Herds range in size from 75 to 6000 reindeer, with most herds numbering 300 1000 animals. Approximately 20 000-25000 reindeer occurred on the Seward Peninsula during the 1980s. Since 1990, this number has declined to 15000 reindeer or less, and perhaps substantially less.

At the time reindeer were introduced to the Seward Peninsula, wildlife was relatively scarce. Caribou (Rangifer tarandus granti) had not occurred here for at least 40-50 years (Skoog 1968); moose (Alces alces) were absent; and there is no biological evidence muskox (Ovibos moschatus) occurred here after the Pleistocene epoch (Guthrie and Lent, pers. comm.). The 20th century brought a resurgence of wildlife to the area: 1) moose immigrated into this area during the late 
$1940 \mathrm{~s}$; 2) muskox were first introduced to the Seward Peninsula in 1970; and 3) during the 1980s caribou began to reoccupy the Seward Peninsula. In addition to fluctuations in ungulate populations, wolf and brown bear abundance on the Seward Peninsula varied substantially between the 1930s and the present time in response to prey availability and human harvest (including government predator control programmes).

This paper provides an historical overview of reindeer and wildlife abundance on the Seward Peninsula during the 20th century. I examine the effects of large ungulates and predators on the reindeer industry and close with a brief description of processes recently employed to manage wildlife for diverse public purposes, including reindeer husbandry. I do not consider moose in this discussion because they affect the reindeer industry only indirectly by providing a stable prey base for brown bears and wolves. The decline of Seward Peninsula moose from 1990 to 1999 has intensified local subsistence hunters' desire for permanent caribou hunting regulations in reindeer grazing areas that could result in the illegal take of reindeer.

\section{Methods}

Estimates of reindeer abundance are based on tallies at corrals and are therefore affected by herd size as well as the proportion of the herd gathered by herders. Caribou population size was estimated using the direct count photo extrapolation technique (Davis et al. 1979): radio-collared caribou were located daily to monitor large, insect-induced aggregations during early July. When caribou were sufficiently aggregated, light conditions were adequate, and the animals were not rapidly moving, each group was photographed from a de Havilland Beaver airplane equipped with a bellymounted large-format $(23 \mathrm{~cm} \times 23 \mathrm{~cm})$ mapping camera. Photographed caribou were later counted to provide a minimum population estimate.

Muskox population estimates are minimum counts based on aerial censuses of all potential muskox habitat on the Seward Peninsula.

Brown bear abundance was estimated using an aerial mark-recapture technique (Miller \& Nelson 1993). This involved fixed-wing aerial surveys of a census area in which an unknown proportion of a brown bear population had been marked with radio collars. The proportion of radio-tagged bears found during visual searches then allowed a ratio estimate of the total population.

\section{Results and discussion}

\section{Reindeer and caribou}

Caribou occurred throughout northern and western Alaska during the early 1800 s but disappeared from areas south of the Brooks Range by the middle of the 19th century (Skoog 1968). Indeed, the primary rationale behind introducing reindeer to the Seward Peninsula was to provide a dependable source of protein for indigenous Inupiat perceived to be suffering from the absence of caribou (Stern et al. 1980).

Caribou began to repopulate Kotzebue Sound during the 1930s, contributing to the complete demise of all reindeer herds in that area, and spread south toward the Seward Peninsula. With the advent of radio telemetry techniques, these caribou were identified as the Western Arctic Herd (WAH) during the late 1960s. The WAH numbered about 243000 caribou in 1970, then declined to approximately 75000 animals by 1976 (Dau in press). From 1975 to 1990, the WAH increased $13 \%$ annually, and from 1990 to 1996 it increased $2 \%$ annually to approximately 463000 caribou. As numbers of WAH caribou increased they reoccupied range where they had been absent for more than 100 years; however, range expansion has not kept pace with population growth. Surprisingly, despite abundant lichens and the presence of reindeer, large numbers of caribou did not move onto the central portion of the Seward Peninsula until autumn 1996, and have still not occupied its western half (Fig. 1). Although this movement of $80000-90000$ caribou (less than $25 \%$ of the entire herd) during fall 1996 was a small extension of WAH winter range, some Seward Peninsula reindeer herds were completely lost as a result. Caribou continued to use this portion of the Seward Peninsula during each fall and winter of 1997-2000, and additional reindeer were lost each year.

Caribou currently have a greater impact on the Seward Peninsula reindeer industry than any other wildlife. Caribou directly affect reindeer: 1) when reindeer join groups of caribou and leave designated ranges; 2 ) through competition for food and 
Fig. 1. Map of the Seward Peninsula, Alaska, indicating seasonal ranges of the Western Arctic Caribou Herd during 1980-2000.

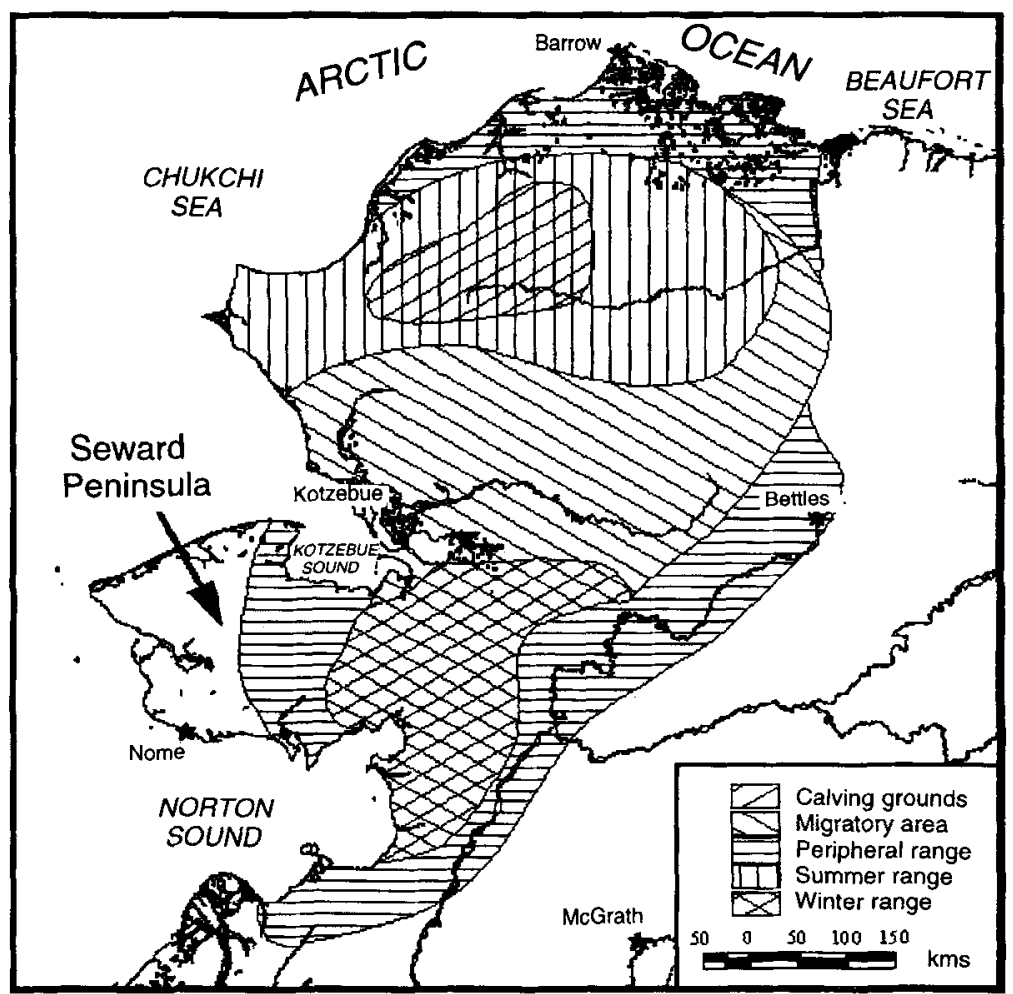

reduction of range quality through trampling; and 3 ) by mixing with reindeer and making them difficult to control. Caribou indirectly affect reindeer by facilitating immigration of wolves into reindeer ranges, and by acting as reservoirs and vectors for parasites and diseases. Currently, the first concern is by far the most serious: 7 of 14 reindeer herds in this region have lost $50 \%$ or more of their reindeer to caribou since approximately 1990.

Herders often cannot protect themselves from reindeer losses due to caribou. Caribou migrate through reindeer ranges during autumn and spring when travel via snow machine is difficult or impossible. Although helicopters are an alternative to snowmobiles for herding, most herders cannot afford them for routine herding. Even if helicopter support was generally affordable, some herders have no portion of their range free of caribou. Also, as few as 7-10 days of inclement weather when herders cannot access their reindeer is enough to lose an entire herd to caribou. When $10000-20000$ caribou engulf groups of reindeer, the sheer number of caribou makes it impossible to separate them, regardless how much support is available.

Loss of reindeer herds imposes social and economic costs on Seward Peninsula residents besides reindeer herders. Income from reindeer herds is distributed throughout villages through complex social traditions, e.g. sharing and support of extended families, and through herders' support of local businesses. Reindeer herders employ local residents thus providing economic opportunities that are extremely limited in remote villages. Ownership of reindeer or employment as a herder conveys high social status in many villages, and loss of a herd can change the social dynamics of a small community. Some people prefer reindeer meat to all other terrestrial wildlife, including caribou.

Aside from reindeer herders, most residents of the Seward Peninsula are delighted to have virtually unlimited opportunity to harvest caribou for sport and subsistence. Although reindeer herders would like to minimize numbers of caribou on the Seward Peninsula, they oppose permanent caribou hunting seasons where caribou 
only recently occurred out of concern that hunters will harvest reindeer while caribou hunting. In contrast, local hunters want permanent, liberal hunting seasons to maximize opportunities to take caribou.

To date, conflicting desires of reindeer herders vs. sport and subsistence users regarding caribou on the Seward Peninsula have largely been addressed through the state regulatory system. In this system, locally elected Fish and Game Advisory Committees, private organizations (e.g. the Reindeer Herders Association), and members of the public provide testimony to the Board of Game (BOG) on existing or proposed wildlife regulations. The BOG then promulgates regulations consistent with the principles of multiple use and sustained yield. On the Seward Peninsula, the BOG initially chose to not establish permanent caribou hunting seasons where reindeer occurred and caribou only recently returned. Instead, the Alaska Department of Fish and Game (ADF\&G) opened caribou seasons by emergency order when caribou move into these areas.

Since 1990, the federal government has managed wildlife for subsistence on federal public lands in Alaska. The Federal Subsistence Board (FSB) consists of the statewide administrative supervisor for each of five federal land management agencies in Alaska, plus one Alaska resident. Its mandate is to provide priority for subsistence uses of wildlife on federal public lands consistent with sustained yield. Co-management of the WAH is currently being developed to supplement and bridge the state and federal regulatory systems, and to increase participation in management decisions by stakeholders, e.g. reindeer herders and hunters, who use or are affected by this herd. Although representation on the co-management working group is still incomplete, this process is already facilitating communication among agencies and users.

In addition to affecting regulations governing caribou harvests, reindeer-caribou conflicts have also influenced $A D F \& G$ caribou monitoring programmes. When caribou are on or near the Seward Peninsula, radio-collared caribou are located as often as weather, day length, budgets and staffing allow, Reindeer herders occasionally participate in these surveys to monitor caribou movements and look for reindeer. Since caribou began to reoccupy the Seward Peninsula, the $A D F \& G$ has increasingly invested in radio collars that transmit directly to satellites partly in response to reindeer herders' requests. These "satellite collars" can be remotely monitored via computer systems when short day length or poor weather preclude aerial surveys. Reindeer herders appreciate these investments in caribou monitoring but remain frustrated that agencies do not do more to minimize reindeer-caribou conflicts.

Reindeer herders and subsistence users recognize that caribou numbers vary widely, both temporally and spatially. Herders predict caribou will again eventually disappear from the Seward Peninsula, but reindeer will persist indefinitely to provide food and income if adequately protected.

\section{Reindeer and muskox}

Muskox were first introduced to the Seward Peninsula in 1970 with an additional transplant in 1981. Since 1970, this population has grown about 14\% annually, to 1797 muskox by March 2000. Muskox have expanded their range to occupy most suitable habitat on the peninsula and are emigrating into adjoining areas.

Muskox are not valued by many residents of the Seward Peninsula, including reindeer herders, for several reasons. The decision to reintroduce muskox to this region was made by the ADF\&G with the aim of eventually providing additional hunting opportunities in Alaska. This decision was made without public participation. Herders and other local residents felt ignored and resented these transplants before they knew anything about the animals. Many subsistence users, especially women, feel threatened by muskox when picking berries or gathering greens. Additionally, most herders and subsistence hunters believe muskox displace Rangifer through aggressive behavior; depositing feces and quiviut (hair) that Rangifer avoid; and competing for food. However, Ihl (1999) found little dietary overlap between these two species during late winter, and no indication that either species affected patterns of habitat use by the other. Likewise, numerous opportunistic observations by me and other ADF\&G staff of muskox and reindeer or caribou peacefully feeding or lying within $200 \mathrm{~m}$ of each other suggests neither species displaces the other.

Since the time of their introduction, the primary management objective for muskox has been to maximize population growth and range expansion. As a result, even limited hunting was not allowed until 1996 and local residents perceived no tangible benefit to offset the costs of these transplants. 
By 1992, the size and growth of the Seward Peninsula muskox population intensified concerns of some subsistence users and reindeer herders, and raised the possibility of sport and/or subsistence hunts. In anticipation of regulatory proposals to the BOG and FSB, an informal, cooperative muskox management planning process was initiated that involved agencies, reindeer herders and the public. Population objectives were re-examined and preferred uses of muskox were prioritized by area.

The management objectives provided in the 1994 Seward Peninsula Cooperative Muskox Management Plan (unpubl.) have guided management decisions by the BOG and FSB. As a result, a muskox viewing area was established near Nome to provide recreational opportunities and income for tourist-related businesses. Also, a limited federal subsistence hunt was established in 1995 for northern and western portions of the peninsula. At the request of the cooperative, a state subsistence hunt was established in 1998 and administered in conjunction with the federal hunt.

Reindeer herders, who are also subsistence hunters, and other subsistence users are pleased that muskox are being harvested. Public appreciation for muskox appears to be increasing as people begin to harvest them for subsistence, and as they become more involved in managing this resource. Although only an ad hoc group with no legal management authority, the cooperative has bridged the state and federal regulatory systems to manage muskox for diverse uses.

\section{Reindeer and brown bears}

Brown bears occur throughout the Seward Peninsula. Most local residents, including reindeer herders, report brown bears are much more abundant now than during the past $30-40$ years. A 1991 population estimate for a $2067 \mathrm{~km}^{2}$ portion of south-central Seward Peninsula indicated there were 29 brown bears of all ages, or 18 brown bears more than 2 years old, per $1000 \mathrm{~km}^{2}$ (Miller \& Nelson 1993).

Brown bears are the most serious predator of reindeer on the Seward Peninsula. Although bears prey on adult reindeer, their greatest impact occurs by taking fawns. Relatively few bears can substantially reduce fawn survival for small reindeer herds. Brown bears can be legally killed at any time in defense of human life or property, and most herders kill brown bears in the vicinity of their herd. Reindeer herders are not compensated for reindeer killed by brown bears.

Reindeer herders want brown bear numbers reduced to minimize losses of reindeer. Most other Seward Peninsula residents also want brown bear numbers reduced because they are perceived as a threat to human life, they damage property and they compete for moose, an important subsistence resource. As a result, in 1997 the BOG lengthened the brown bear sport hunting season, increased the sport hunting bag limit and established a new, liberal subsistence hunt on the peninsula. Biologists have urged the BOG to manage brown bears conservatively because their abundance is difficult to monitor, compliance with harvest reporting requirements is poor among local residents, and brown bears have intrinsically low productivity.

\section{Reindeer and wolves}

There is no quantitative estimate of wolf abundance anywhere on the Seward Peninsula. Herders report wolves were abundant throughout this area during the 1930s and contributed to the decline of reindeer during that time. Since the early 1980 s wolves have been scarce in the central and western portions of the peninsula. In contrast, local hunters and reindeer herders report wolves are currently abundant near the base of the Seward Peninsula, and are increasing in areas recently occupied by caribou.

Wolves are an important mortality source for reindeer herds in the eastern portion of the Seward Peninsula where reindeer herds have been diminished by caribou. Reindeer herders have unsuccessfully requested that the BOG re-establish lethal wolf control programmes to reduce depredations on reindeer. Reindeer herders are not compensated for reindeer killed by wolves.

Many Seward Peninsula hunters value wolves for their fur, for the prestige associated with taking wolves, and for income derived from selling pelts. Most local hunters do not want to reduce wolves as long as they are not perceived to be limiting important subsistence species, e.g. moose or caribou, and they generally oppose government wolf control programmes. Like reindeer herders, local hunters desire liberal seasons and bag limits to maximize their harvest of wolves. In contrast, a growing segment of nonlocal society opposes wolf reductions for any reason.

Wolf management in Alaska has been highly contentious for more than 20 years despite 
intensive research on predator/prey relationships throughout the state, and public participation in management processes. Currently, wolf management on the Seward Peninsula and other portions of Alaska is influenced primarily by statewide policies rather than local biological considerations or public desire. Reindeer herders are frustrated that agencies have not reduced wolves in problem areas; agencies are frustrated by political restriction of management options for wolves; and polarized users are frustrated because too few or too many wolves are being harvested.

\section{Conclusions}

Despite large fluctuations in abundance, reindeer have been a significant biological component of the Seward Peninsula and herding has been an important social and economic force in communities of the region for about 100 years. The resurgence of wild ungulates and large predators on the peninsula during the last $40-50$ years has significantly impacted the reindeer industry and created diverse management issues. Caribou currently affect the Seward Peninsula reindeer industry more than any other wildlife primarily when reindeer join groups of caribou and leave herders' designated ranges. Caribou and reindeer also compete for food. Muskox may displace reindeer from their range, although scientific evidence does not support this. Muskox may also compete with reindeer for food during severe winters when snow restricts access to vegetation, or when these species reach high densities. Additionally, wolves and brown bears reduce reindeer numbers through predation.

Wildlife management on the Seward Peninsula, as elsewhere in Alaska, has become more complex since reindeer were introduced. Two overlapping wildlife regulatory systems, one administered by the state and the other by the federal government, operate independently under different mandates to manage the same populations of wildlife. Land ownership is a patchwork quilt of policies that affect access to grazing and wildlife. Also, public desires regarding wildlife, including those of reindeer herders, are diverse. As a result, informal, cooperative public processes have been initiated to supplement and bridge the state and federal regulatory systems, and bring diverse interests together. These processes have emphasized cooperation among agencies, reindeer herders and other users to develop management recommendations through consensus. They have also been an effective means of melding indigenous, scientific and local knowledge in management programmes.

Acknowledgements. - I thank Dr. J. W. Coady and Dr. D. R. Klein for their constructive reviews of this manuscript, and for their years of quiet mentoring through my professional career. 1 also thank numerous Seward Peninsula reindeer herders, particularly Mr. L. T. Davis, for teaching me about reindeer and herding.

\section{References}

Dau, J. in press: Units 2/D, 22A, 22B, 23, 24 and 26A caribou survey-inventory management report. Fed. Aid in Wildl. Resl. Progress Rep. Grants W-24-5 and W-27-1. Juneau: Alaska Dept. of Fish and Game.

Davis, J. L., Valkenberg, P. \& Harbo, S. J. 1979: Refinement of the aerial photo-direct count-extrapolation caribou census technique. Fed. Aid Wildl. Rest. Proj. Rep. Proj. W-17-11, Job 3.25R. Juneau: Alaska Dept. of Fish and Game.

Ihl, C. 1999: Comparative habitat and diet selection of muskoxen and reindeer on the Seward Peninsula, western Alaska. M.Sc. thesis, University of Alaska.

Jackson, S. 1906: Fifteenth report on introduction of domestic reindeer into Alaska. Washington, D.C.: Government Printing Office.

Miller, S. D. \& Nelson, R. 1993: A brown bear density and population estimate for a portion of the Seward Peninsula, Alaska. Fed. Aid in Wildl. Rest. Management Rep. Suppl. Proj. W-23-4 and W-23-5. Study 4.0. Juneau: Alaska Dept. of Fish and Game.

Skoog, R. O, 1968: Ecology of the caribou (Rangifer tarandus granti) in Alaska. Ph.D. diss., University of California, Berkeley.

Stern, R. O., Arobio, E. L., Naylor, L. L. \& Thomas, W. C. 1980: Eskimos, reindeer and land. Fairbanks: University of Alaska.

Vorren, O. 1994: Saami, reindeer, and gold in Alaska. Prospect Heights, IL: Waveland Press. 